\title{
Město jako domov a znázornění jeho vlivu na formování národní identity v současné ukrajinské literatuře
}

Krystyna Kuznietsova (Brno)

\begin{abstract}
Abstrakt
Začátek 21. století je poznamenaný postmodernou a vnáší do ukrajinské literatury nová témata a žánry, projevuje se dřive zakázanou hravostí a pestrostí jak postav a námětů, tak i lexikálním obohacením textů. Jinak je tomu však po první dekádě 21. století. Hlavní hrdinové současných románů, jejichž autoři zpracovávají historická traumata, se proměnili, vzhlíži k minulosti pro přehodnocení a pochopení tohoto světa, ale možná ještě nepřestali ve svém hledání a potřebují projít další cestu sebepoznání, aby se zastavili a zcela určili svoji identitu. Často nevzhlížejí k místu narození, které pro mnohé z nich znamenal SSSR, ale k místu stávajícího bydliště - k městu, které jako živý organismus ovlivňuje utváření nového občana. Pro tuto práci vybíráme romány V. Ameliny Dům pro Doma (2017) a J. Kozlenka Tanger (2017), jejichž odlišnosti a podobnosti ilustrují některé stereotypy obyvatel Lvova a Oděsy.
\end{abstract}

\section{Klíčová slova}

ukrajinská literatura; současná literatura; město; národní literatury; národní identita

\section{Abstract \\ The City as a Home and Reflection of its Influence on the Formation of National Identity in Contemporary Ukrainian Literature}

The beginning of the 21st century is marked by postmodernism and brings new themes and genres to Ukrainian literature, manifested by the previously forbidden playfulness and variety of both characters and themes, as well as lexical enrichment of texts. However, after the first decade of the 21 st century the situation is different. The protagonists of today's novels have changed, looking at the past to rethink and understand this world, but they may not have stopped searching and need to go further on the path of self-knowledge in order to stop and fully determine their identity. They often do not look at the place of birth, which for many of them meant the USSR, but at the place of current residence - a city that, as a living organism, influences the formation of a new citizen. For this work, we select the novels by Viktoria Amelina Home for Dom (2017) and Jvan Kozlenko Tangier (2017), whose differences and similarities are refuted or confirmed by some stereotypes of the representatives of Lviv and Odessa.

\section{Key words}

Ukrainian literature; contemporary literature; the city; national literature; national identity

Tento výstup vznikI na Masarykově univerzitě v rámci projektu Slavistická badatelská dílna číslo MUNI/A/0900/2019 podpořeného z prostředků účelové podpory na specifický vysokoškolský výzkum, kterou poskytlo MŠMT v roce 2020. 
Minulost v ukrajinské literatuře hrála klíčovou roli, obzvláště po roce 1991, kdy vznikla nezbytná potřeba obohatit ukrajinské dějiny literatury nejenom dříve zakázanými díly a vydáními, ale i přehodnotit teorii literární vědy a vrátit literatuře její národní znaky. Minulost se tak stala pro literární vědce, kritiky a samotné spisovatele počátečním bodem v hledání národního sebepoznání. Tuto problematiku vyskytující se v ukrajinském románu můžeme rozdělit do třech klíčových skupin: 1. hledání své identity ve složitém období války (např. Serhij Žadan Internát (2017)), 2. návrat k minulosti za účelem přehodnocení současnosti (romány Natalky Sňadanko Spořádané spisy arcivévody Viléma (2017) a Tetjany Maljarčuk Zapomenuti (2016)). Poslední možností hledání své identity je třetí skupina literárních děl - próza míst a měst. Tady jako př́ílad můžeme uvést román Viktorije Ameliny Dưm pro Doma (2017), jenž pojednává o snaze nalezení lásky k cizímu městu, sbírku povídek Kateryny Kalytko Země ztracených nebo malé děsivé pohádky (2017), jež nás seznamuje s příběhy lidí bez pocitu domova a státu, román Jvana Kozlenka Tanger (2017) rozkrývající všechna tajemství města Oděsy a knihu Markijana Kamyše Čormet (2017) vyprávějící o lidech, jejichž živobytí závisí na mizerném a škaredém místě bydlení.

Klíčovým pro ukrajinskou literární vědu je i uvědomení si počátku současné literatury. Například přední ukrajinská literární vědkyně Tamara Hundorova se zaměřuje na texty spisovatelů po roce 1986, tzv. „post-černobylskou“ literaturu, kterou považuje za počátek současné literatury. Jedná se ale o postmoderní diskurz, proto je vhodné i poukázat na to, že v jednotlivých slovanských státech postmoderna vznikala a naplňovala se odlišně, ${ }^{1}$ čímž vyvolávala kolem sebe polemické diskuse (např. o existenci východoevropského postmodernismu). Avšak v novém tisíciletí, jak to výstižně postřehla Alena Fialová, postmoderna ustupuje: „Pomalu se vyčerpával také boom postmodernich experimentálnich próz: postmoderna ztratila punc prekvapujicího a provokujicího gesta a stala se - vedle jiných poetik a výrazových prostředků - organickou součástí individuálnich literárních stylů. "2 Proto se v této práci zaměříme spíše na plochu vzniklou v 21. století pro stvoření nových děl s odlišnou tematikou a poetikou, která odrážela aktuální společenské problémy a život v postkomunistické době, klíčové pro současnou ukrajinskou literaturu téma rekonstrukce individuální historické paměti a historického traumatu.

S odstupem postmodernismu je ukrajinská próza poznamenaná neomodernismem, a texty jsou často ustálené v realistickém stylu. Avšak v ukrajinském neomodernismu jsou pozůstatky předešlé problematiky, o které se mnohokrát zmiňuje ve svých monografiích Tamara Hudorova, to jest bezdomovectví v ukrajinské literatuře konce devadesátých let minulého století. Nejedná se samozřejmě o přímou ztrátu vlastního domova, ale spíše o ztrátu pocitu domova. Mnohdy se postavy románů a lyričtí hrdinové poezie vydávají na cestu vyhledávání něčeho, co by mohli považovat za svůj domov. Jsou poznamenaní

1 V české literatuře je jedním z prvních představitelů postmoderního směru Jiří Kratochvil (povídky Má lásko, postmoderno (1994) a Vyznáni postmodernisty (časopisecky jako Štastný Sisyfos, 2001) považován za manifest české postmoderny); v bulharské literatuře podobné hledání třeba najdeme u Georgiho Gospodinova, ukrajinská postmoderna je reprezentovaná tvorbou literární skupiny Bu-Ba-Bu (nejvýraznější je tvorba Juryje Andruchovyče). Tvorba těchto autorů zahrnuje výrazné postmoderní prvky (hra s textem, časem a žánry, tzv. „karneval“ apod.), ale je poznamenaná i osobitou poetikou.

2 FIALOVÁ, Alena (ed.): V souřadnicích mnohosti. Česká literatura pruni dekády jednadvacátého století v souvislostech a interpretacich. Praha: Academia, 2014, s. 341. 
neustálým putováním - po městě, ve státě a do minulosti, což formuje zlomkovité vědomí moderního člověka. ${ }^{3}$ A to už uplynulo více než deset let, kdy nám Žadanův Depeš Mod (2004) představil mladou generaci rozpačitých Charkovanů, psychicky traumatizovaných a znejistěných ve své existenci. Byl to začátek 21. století poznamenaný postmodernou, kdy se ukrajinská literatura obohatila o nová témata a žánry. A tento směr se projevoval dříve zakázanou hravostí a pestrostí jak postav a námětů, tak i lexikálního obohacení textů. Jak uvádíme výše, v desátých letech 21. století je tomu jinak. Spisovatelé ve svých literárních dílech přehodnocují minulost, zpracovávají pochopení vlastní minulosti, a tak trauma, vzpomínaní a pamět se stávají pro ukrajinskou prózu velmi frekventovaným jevem. Hlavní hrdinové současných románů se proměnili, vzhlíží k minulosti pro přehodnocení a pochopení tohoto světa, ale možná ještě nepřestali ve svém hledání a potřebujî projít další cestu sebepoznání, aby se zastavili a zcela určili svoji identitu. Často nevzhlížejí k místu narození, které pro mnohé z nich znamenalo SSSR, ale k místu stávajícího bydliště - k městu, které jako živý organismus ovlivňuje utváření nového občana. Tudíž je zajímavé pozorovat transformaci postav v novějších prózách ukrajinských spisovatelů (po roce 2014) a nelze zcela jistě odpovědět, jestli jejich hledání svého místa a domova je konečně u konce. Možná, že získali pocit domova anebo představu o tom, jaký by měl být - a častěji za něj počítali město, ve kterém vyrůstali a které se stalo jejich útočištěm. Nicméně se nezbavili nutnosti nahlížet do minulosti, která se opakovaně objevuje v současných dílech ukrajinského knižního trhu. A znovu se minulost stává klíčovou k nalezení odpovědí na existenciální otázky a pochopení svého místa v ukrajinské společnosti. To poslední je někdy velmi těžké vzhledem k minulosti a politice Sovětského svazu, jejímž účelem bylo sjednocování národů tak velkého území, což se dosahovalo díky neustálému stěhování rodin. To však byla idealizovaná představa, protože místo narození doprovázelo tyto přestěhovalce celý život, navzdory žádoucím snahám vlády vytvořit umělou národnost. Nasvědčuje tomu i tehdejší populární píseň, ve které se zpívalo: „Моŭ aдpec не дом и не улича. Мой адрес - Советский Союз“". Model postkomunistického traumatu je charakteristický pro většinu společností bývalých komunistických států, jakožto i trauma celkem je „podstatnou kategorii kulturni zkušenosti dvacátého stoleti [...]. A důsledkem tohoto ničivého procesu je ztráta smysluplného uspořádáni a vnímáni světa a může se objevit $i$ masivni narušeni sebevnímáni a identity. "5

Ukrajinská socialistická republika nebyla výjimkou, často se stávala novým domovem pro rodiny ze vzdálených zemí, mnohdy pro i rodiny, jež se stěhovaly téměř nepřetržitě a Ukrajina pro ně byla poslední zastávkou. Právě z mnoha takových rodin pochází řada současných Ukrajinců, kteří se možná až příliš dlouho zastavili v nadčasovém prostoru. Neboli generace narozená v 80. letech a vychovaná v 90 . letech se nemůže posunovat dále vpřed a neustále se vrací k minulosti. Pravděpodobně je to nezbytný postup, jak se oprostit od traumatizované zkušenosti. A tak i téma rodinné historie, které je oblíbené

3 HUNDOROVA, Tamara: Pisljačornobylska bibloteka. Ukrajinskyj literaturnyj postmodernizm. Kyjiv: Krytyka, 2005, s. 159-176.

4 „Moje adresa neni dům, ani ulice. Moje adresa je Sovětský svaz.“ (skupina Samocvěty, rok 1973).

5 KRATOCHVIL, Alexandr: Pamět a trauma pohledem humanitních věd: Komentovaná antologie teoretických textů. Praha: Akropolis, 2015, s. 93. 
pro ukrajinskou literaturu všech dob, v současných prozaických dílech směřuje k problematice vychování nejmladší generace v sovětské „multikulturní“6 rodině, jelikož i dnes „více než čturtina (27\%) respondenti̊ (pozn. autorky - průzkumu veřejného mínění) se na Ukrajině považuji za občany bývalého SSSR.“7

Problematika identity a historické paměti je velmi klíčová nejen ve tvorbě autorů starší generace (Oksana Zabužko Muzeum opuštěných tajemstvi (2009), Valerij Ševčuk Stíny co mizi (2002), Jurij Vynnyčuk Tango smrti (2012), Stepan Procjuk Byliny nemohou umř́t (2017) aj.), ale najdeme ji i u představitelů mladší literatury, nap̌r. u Oleha Kocareva Lidé v hnizdech (2018), již zmíněných - Natalky Sňadanko Spořádané spisy arcivévody Viléma (2017) a Tetjany Maljarčuk Zapomenuti, (2016), Viktorije Ameliny Di̊m pro Doma (2017), Kateryny Kalytko Země ztracených nebo malé děsivé pohádky (2017), Jvana Kozlenka Tanger (2017), Markijana Kamyše Čormet (2017) a řady dalších.

Ukrajinská spisovatelka Viktorija Amelina ${ }^{8}$ ve svém románě Di̊m pro Doma (2017) velmi výstižně popisuje př́běh jedné z takových rodin, která se ocitla ve Lvově a potýkala se s mnoha problémy, včetně sebereflexe a pochopení své národnosti. Je to př́íběh o složitosti zapadnout do cizího světa a o nepříslušnosti v něm, o neporozumění mezi lidmi, kteří mají stejné občanství, ale rozdílnou výchovu a zvyky. Lze podotknout, že je to i tragédie osudů lidí, kteří se necítí doma nikde, nemají žádnou vlasteneckou př́íslušnost, a proto ztrácejí jakoukoliv identitu. Často se nechtě stávají outsidery nejprve vlastního života, a pak i politicko-sociálních, kulturních a dalších procesů. Tato problematika je citlivá a pochopitelně může působit klamavým dojmem, že jsou skutečnosti popsané jednostranně a subjektivně; možná proto si spisovatelka pro zachování svého nestranného postoje vybírá jako vypravěče svého prozaického díla psa, protože: „Copak trápi psy problém politického národa a dobrovolně zvolené identity?" Nikoliv, tak stejně je nemůže trápit problém hledání domova, pro psa je totiž odpověd' jednoduchá - dům je tam, kde je tvůj pán.

Ze začátku příběh není o nalezení domova, ale naopak o jeho ztrátě. Po nesplnění svého poslání loveckého psa se pudl jménem Dom stěhuje z neexistujícího města Noversk do Lvova k majitelově dceři. Musí bydlet v nové rodině, protože tak zněl povel pána: „Tym dis!“10. Ale ještě dlouho nebude vnímat nové město jako svůj skutečný domov, stejně jako i jeho noví „majitelé“ - plukovníkova rodina, která často bydlela v různých částech Sovětského svazu a byla připravena se kdykoliv přesunout: „Tут складено все, шо може знадобитися потім, у тому житті, яке колись розпочнеться, - невідомо коли, й невідомо,

6 Dáváme do uvozovek, jelikož mnohdy starší generace se v těchto rodinách neidentifikovala s žádnou národností anebo se sama nazývala „sovětskými“ občany.

7 Centr Razumkova: Osnovni zasady ta šjjachy formuvannja spilnoji identyčnosti hromadjan. Informacijno-analityčni materiály do kruhloho stolu 12 kvitnja 2017 roku. Kyjiv: Cent Razumkova, 2017, s. 14. (https://lb.ua/ culture/2017/09/06/375749_tilki_plach_nova_ukrainska_proza.html).

8 I v předchozím románu autorky Syndrom listopadu nebo Homo Compatiens (2014) najdeme postavy „na cestě“, „bez domova“, poznamenané traumatickým minulým.

9 „Чи болить собакам проблема політичної наиї та добровільно обраної ідентичності?“. ULJURA, Hanna: Dvi knyžky pro radjanske mynule. Viktorija Amelina „Dim dlja Doma“ [online 20. 4. 2019: https://lb.ua/culture/2017/09/06/375749_tilki_plach_nova_ukrainska_proza.html].

10 „Tady je di̊m!“ AMELINA, Viktorija: Dim dlja Doma. Lviv: VSL, 2017, s. 29. 
яка ще війна має для иъого скінчитися. А поки майбутнє чекає на книжкових поличях, у шафах, на шафах, в сервантах і під ліжками в коробках."11 Tо ještě víc potvrzuje kočovný způsob života těchto lidí, kteří ve zmatcích neustálého stěhování zapomněli na zvyky a tradice, na svoje kořeny a jediné, co jim zůstalo, bylo doufat v lepší budoucnost. Jsou tady znázorněny tři generace - nejstarší plukovník Ivan Cilyk a jeho žena Lilja, jejich dcery Tamara a Olja a dvě vnučky Marie (Maša i Marusja) jako nejmladší představitelky této rodiny. Každý prožívá svoje osobní životní drama, kde své místo nachází i otázka národní identifikace, protože přece každý musí mít nějakou příslušnost, nehledě na to, že se s vědomím, do kteréžto národnosti patříme, nerodíme, ale během dospívání v sobě vychováváme názornost, která nás dovede $\mathrm{k}$ tomu poznat, do jakého národa patříme. ${ }^{12}$ Jenže př́íslušníci rodiny Cilyka už neznají, nebo nikdy neznali svoji národnost, dokonce i úředně: „У свідочтва про народження своїх дітей Іван та Ліля записали різні начіональності: Тамарі- «росіянка», Олі-«украӥнка». Ніби підкоряючись розтиражованій ідеї старшого й молодшого брата. Обидві онуки вже якимось дивом народилися росіянками."13

Obě postavy dcer jsou typickým obrazem žen této doby - jsou rozvedené a zklamané životem. Starší Tamara je bez práce a často sahá po lahvi s vodkou, jediné, co ji pak zachrání od alkoholismu, je emigrace za prací do Španělska. Olja pracuje jako učitelka dějepisu, zanedlouho však podá výpověd', jelikož po inspekci ve škole zjistí, že se pro tuto práci nehodí, protože zná jen sovětské dějiny a necítí se být dobrou učitelkou v nové ukrajinské společnosti. Na rozdíl od Tamary, která se identifikuje jako Ruska: „Вона ж визначала себе за матір’ю, яка не дуже, м’яко кажучи, знала свій родовід, - росіянкою. "14 Olja je v otázkách sebereflexe nejvíce v nesnázích. Život ve Lvově ji proměňuje, z nouze se například naučí ukrajinsky, ale stále to však není její domov: „I хоча в Олиному радянському паспорті написано ж було чорним по білому «украӥнка», иі прапори їи - чужі, й мова - чужа, й місто ие раптом - чуже, та, як $i$ для більшості радянсвких людей..."15 Nehledě na to, že všechno pro ni je tady cizí, neví, kde tomu tak není, protože i zdánlivě jednoduchá otázka „odkud je“ dokáže znepokojit její mysl: „Звідки? Мама Оля застигла й мовчала. Що вона має відповісти? I справа не в тому, аби знайти правильну відповідь для перевірки. Просто справді, а звідки вона? Можливо, вона з Баку? [...] А може, вона з селиша на Забайкаллі, де ходила до першого класу? А може, з якого-небудь Саратова, де й не бувала ніколи, бо звідти втекла від невідомих бід ще ї бабуся, за течією Волги аж до Каспійського моря. Чи, може, Оля таки з Украӥни? 3 села, куди скоро поїде батько ставити

11 „Tady je vše, co bude potřeba později, v životě, který jednoho dne začne - neni známo kdy a neni známo, která válka ještě musi skončit do té doby. Mezitím budoucnost čeká na knižnich poličkách, ve skř́nich, na skř́nich, v kredencích a pod postelemi v krabicich." Tamtéž, s. 49.

12 KAUTMAN, František: O českou národni identitu. Praha: Pulchra, 2015, s. 171.

13 „Ivan a Lilja uvedli v rodných listech svých děti různé národnosti: Tamara je Ruska, Olja je Ukrajinka. Jako by se ř́dili rozšírenou myšlenkou o staršim a mladšim bratrovi. Obě vnučky se zázračně už narodily jako Rusky." Tamtéž, s. 79 .

14 „Identifikovala se po matce, totiž jako Ruska, i když sama matka, jemně řěeno, dobře neznala svůj rodokmen.“ Tamtéž, s. 249.

15 „I kdyžv Oljině sovětském pase bylo napsáno černé na bilém „Ukrajinka“, tyto vlajky byly pro ni cizí, jazyk byl také cizi, najednou se i toto město stalo cizím, však jak i pro většinu sovětských lidí... Tamtéž, s. 157. 
пам'ятник на могилі своєї матері. Звідки вона? - Мама Оля просто ніколи про ие не думала..."16

Zajímavou možnost odpovědět na tento neutuchající dotaz v románě jim nabízí samotná autorka, která vkládá do úst nevinného pejska lidské moudrosti - jsou to lidé odnikud a odevšad. O tomto se dozvídáme hned z prvních stránek: „нові знайомі, може, люди і непогані. Та здається, прийшли сюди, хоч і давно за моєю міркою, але чи то нізвідки - чи то звідусюди. "17 Zanedlouho k takovému závěru dojde i nejstarší z žen v této rodině - Lilja Cilyk: „Якби раптом взяласъ вона переписати всі иі рецепти так, щоб з гучним заголовком, як в пані Віри, щоб ие вийшла за збірка? "Нічиї рещепти»? "Сочіалістичні реиепти»? «Реиепти звідусюди й нізвідки»? Так, здається так було б добре - звідусюди й нізвідки. "18 Není to náhoda, její maminka možná i bydlela v Baku, ale neměla nic kromě domu, kterého se usilovně nechtěla vzdát: „Плакала, чіплялась за стіни барака. [...] Щосъ же Ніну тримало в Баку. Зрештою, в неї-ні релігї, ні наиіональності, навіть із класовим походженнам не все ясно, - тільки дім $і$ був. "19 Domnívám se, že podobně jako její matka, Lilja taky neměla ani národní, ani náboženské preference, ale za svůj domov vždy považovala Baku: „I коли хтось із новоприбулих дітей партійних робітників або інженерів, які приїхали "підіймати республіку», вимовляв «ми, росіяни», кивала, мовляв, так-так, ми та геть нічого не відчувала. Там, на гарячому березі, де після купання часом лишиться на купальнику нафтова пляма, був ї̈ дім - двір, оплетений виноградом, маленька «басейка» з крижаною водою, де чекає на тебе найсмачніший у світі кавун, і дід-іранещь Алі, який їи насправді, звісно, не дід, але так вона його називала - ніколи не мала іншого діда. Це був ï̈ дiм. "20

Zdá se, že jediný, kdo přesně věděl o svém původu, byl plukovník, který vyrůstal ve vesničce Krajnovka v Charkovské oblasti. Je ale zřejmé, že za všechna ta léta služby v sovětské armádě se do jeho podvědomí vryl jakýsi zákaz být Ukrajincem. Už v mladí se svým kamarádem z Doněcka mluvil nějakým ukrajinským nářečím: „Говорили ж майже однаковою говіркою (не при чужих, поміж собою).“21 Nejen s kamarádem si rád zavzpomí-

16 „Odkud? Máma Olja znehybněla a mlčela. Co má odpovědět? A nešlo o to najít správnou odpověd’ pro komisi. Ne. Prostě odkud je doopravdy? Možná, z Baku? [...] Anebo z vesnice na Zabajkalsku, kam chodila do prvni tř́dy? Anebo z nějakého Saratova, kde nikdy nebyla, protože odtamtud utekla jeji babicka. Utikala z neznámých dĩvodi̊ po proudu Volhy až ke Kaspickému moři. Anebo je prece z Ukrajiny? Z vesnice, kam zanedlouho pojede jeji otec stavět pomnik na hrob své matky. Odkud je? - Máma Olja prostě nikdy o tom nepremýšlela...". Tamtéž, s. 116.

17 „noví známi možná nejsou špatni lidé. Ale zdá se, že sem př̌šli, byt dávno podle mých měrítek, ale bud' odnikud, nebo odevšad." Tamtéž, s. 31.

18 „Kdyby najednou chtěla sepsat všechny tyto recepty tak, aby kuchařka měla křiklavý název, jak to má paní Věra, jaká by to byla sbírka? "Niči kuchyně»? «Socialistická kuchyně»? «Recepty odnikud a odevšad «? Ano, zdá se, že by to bylo nejlepši - odnikud a odevšad." Tamtéž, s. 77.

19 „Plakala a držela se zdi baráku. [...] Něco přece drželo Ninu v Baku. Koneckonců neměla žádné náboženstvi, žádnou národnost, dokonce i se společenskou tř́dou to u ní nebylo jasné, měla jen dům. " Tamtéž, s. 58.

20 „I když někdo z děti stranických dělniků nebo techniků, kteři nově dorazili, aby prišsli „povznést republiku“, řekl „jsme Rusové, “ přikývla, jako, že ano, ale vi̊bec nic necítila. Tam, na horkém břehu, kde někdy po koupáni zůstane na plavkách ropná skvrna, byl jeji dům - dvuir obklopený vinnou révou, malá studená vodni lázeň, ve které na tebe čeká meloun nejchutnějši na světě, a iránský dědeček Ali, který ve skutečnosti není žádný dědeček, ale ř́kala mu tak, protože jiného dědečka nikdy neměla. Byl to jeji domov." Tamtéž, s. 79.

21 „Mluvili skoro stejným nářečim (ale ne s cizími, jenom mezi sebou). “ Tamtéž, s. 47. 
nal na domov, ale i na samotě: „Кричав украӥнською посеред карельсвких сосон, як серед свойх. Хто його там чув? Хіба ио диспетчер. Хто його там розумів? Хіба привиди."22 То, že by se Ivan Cilyk chtěl cítit být Ukrajincem naznačuje v románě i jeho účast na demonstraci, kde ho jeho dcera Olja jednou viděla mezi mladými lidmi s ukrajinskými vlajkami. Doma o tom ale nemluví. Plukovník si to nechává jako tajemství a dokonce nikdy nevyslovuje název svého státu: „[...] «y нас», як каже Цілик - я вже знаю - про Україну. Він наче боїться вимовляти назву своєї країни, тільки «у нас» $i$ все - як пароль. "23 „[...] він же ніяк не хоче вимовляти всує ие слово - «Украӥна»."24 A tak vzniká jedinečný druh postavy, vždy trochu bojácný, bez konkrétního sebecítění a vyjádření vlastního postoje, protože Ivan Cilyk: „[...] не був ні священником, ні дворянином, ні євреєм, ні ромом, ні буржуазним начіоналістом, ні польсъким офічером у полоні, ні надто иирим комуністом."25 Je to docela příznačné v ukrajinské literatuře posledních let, podobného hrdinu najdeme například v románu Volodymyra Lysa Stoleti Jakova (2010). Autor dokázal mistrovsky zmapovat život celého ukrajinského Polesí na příkladu jedince, jenž se dožívá svých sta let a vzpomíná na tragické události, střídání vlád a na války. Nehledě na tyto skutečnosti je hlavní hrdina Jakiv apolitický a tolerantní, ve víru 20. století věří jen na lásku, a proto se stává objektivním pozorovatelem nahlížejícím do tváře rodinného a národního dramatu této doby. Samozřejmě, obě postavy nemůžeme př́ímo ztotožnit, první je „produktem“ sovětské doby, a druhý přežil ve víru dramatických události 20. století, ale propojuje je smíření s osudem a v jistém smyslu očekávání změn.

Nehledě na teorii fikčních světů, kde postavu nemůžeme ztotožnit s opravdu existujícím člověkem, jelikož nežije ve skutečném světě, ale v autorem vymyšlené umělecké realitě, jsou to postavy velmi realistické. A to potvrzuje, že v př́ípadě takovéhoto nahlížení na postavu se fikční svět stvořený spisovatelem často a nevyhnutelně prolíná s tím naším skutečným. ${ }^{26}$

Viditelná intence románu je vzbudit rozpor osobní i celostátní, dokonce i město podléhá historické roztržce, protože minulé události není možné setřít, jejich vliv potrvá ještě dlouhou dobu: „Велика страшна краӥна розбилася й розлилася, як розливається часом олія, куплена на Привокзальному ринку якоюсь львівською пані. Краӥна розтікалася бруківкою струмочками, ріками. I так просто ї̈ не витреш із вулищъ."27 A tak i město s bohatou evropskou minulostí není možné okamžitě přeměnit, protože doba vládnutí komunistického režimu bezpochyby zanechala stopu i na něm. Lvov v knize není ztvárněn

22 „Křičel ukrajinsky uprostřed karelských borovic, jako by byl mezi svými. Kdo ho tam slyšel? Leda tak dispečer. Kdo mu rozuměl? Leda tak duchové." Tamtéž, s. 171.

23 „[...] jak říká Cilyk „u nás“, a já už vím, že o Ukrajině. Jako kdyby se bál vyslovit název své země, jenom „u nás“, nic vic - jako nějaké heslo." Tamtéž, s. 173.

24, „...] i nadále nechce nadarmo vyslovit to slovo - „Ukrajina“.“ Tamtéž, s. 197.

25 „nebyl to ani kněz, ani šlechtic, ani Žid, ani Rom, ani buržoazni nacionalista, ani polský diostojník v zajetí, ani moc upřimný komunista." Tamtéž, s. 380.

26 FOřT, Bohumil: Úvod do sémantiky fikčnich světư. Brno: HOST, 2005.

27 „Velký hrůzostrašný stát se zhroutil a rozlil se, jak se rozlije někdy olej, koupený na Pryvokzalném trhu nějakou lvouskou paní. Země se roztekla po dlažbě, jako potoky a řeky. A tak jednoduše ho nejde vytř́t z ulic." AMELINA, Viktorija: Dim dlja Doma. Lviv: VSL, 2017, s. 10. 
jenom ulicemi, které svým čichem symbolicky prozkoumává pes Dom a dotykem slepá vnučka Marusja. Jsou tu i postavy zakořeněných obyvatel - nepřátelský soused Jaroslav Teodorovyč, který si myslí, že plukovníkova rodina nepatří do tohoto města, protože o něm nic neví a nevidí ho. I tito obyvatelé Lvova se drží minulosti, jenom je to minulost spjatá s Rakousko-Uherskem, které oni vyzdvihují, schovávají se za ušlechtilou inteligentností a tradicemi, kterým údajně zůstávali věrní i v USSR. Neupřímnost těchto postav se projevuje v drobných lžích, např́klad druhá babička Marusjy, paní Věra - Lvovanka, která odsuzuje rodinu Cilyků za jejich „sovětskost“, si nalhává, že pojmenovala svého syna na počest svatého Jiř́ího, do jehož chrámu chodí každou neděli. Pravdou ale je, že jméno Jurij má Marusjin otec po slavném sovětském kosmonautovi Gagarinovi. ${ }^{28}$

Román nás nutí k zamyšlení nad bílou skvrnou v historii, zmiňuje ji v rozhovoru o knize i Viktorija Amelina: „V románu je epizoda, kde dívka musí vyprávèt o své rodině ve škole. Bere fotografii se suým dědečkem, který je v uniformě sovětské armády. Ale dospèli ji ř řkaji, že to neni to, na co se musi zaměřit a o čem musi mluvit. Vzniká určitá bilá skvrna. Protože, i když dokážeme odstranit sovětské symboly na stěnách stanice metra, není možné je vyškrtnout z rodinných fotografí. Musime tedy chápat naši historii jiným zpơsobem. " ${ }^{99}$

Na rozdíl od jiných ukrajinských knih a románů, ve kterých autoři líčí život tehdejší doby, není toto dílo napsáno dramatickým stylem, nenajdeme tady přehnané zveličování jedněch postav, ani kruté odsuzování jiných. Autorka vzhlíží k této době vesele a s ironií, však i nejsmutnější příběh je lépe popsat s humorem, protože je to „zpưsob, jak préd


ani nemusí řešit, jakým jazykem příběh vyprávět, postačí mu čich. ${ }^{31}$ To vytváří osobitou symboliku, protože ulice již byly přejmenovány a změnily se vlajky na domech, ale vưně v tomto městě jsou ukotvené po celá desetiletí. Domy a ulice vyprávějí Domovi příběh lépe než jakákoliv učebnice.

Právě taková literatura, kterou nám nabízí Viktorija Amelina, je důležitá pro dnešní generaci, abychom horlivě neodsuzovali, nezveličovali, byli více sebekritičtí a nahlíželi na minulost s nadhledem.

I v tomto díle současné ukrajinské literatury důležitým aspektem zůstává město, autoři stále vnímají vliv metropole jako nedělitelnou součást člověka, jeho vnímání světa a také i formování jeho názorů. Městu není přidělená vlastní role postavy, jak tomu bylo třeba u V. Pidmohylného, ale má velký vliv na formování vnitřního charakteru protagonisty a jeho světonázoru. Podobně jak i rodina Cilyka, představující člověka ovlivněného komunistickou dobou (nikoliv však komunistu), Lvov zatím také neví a čeká: „Львів поки

28 „I хороме ж ім'я. I Гагарін - сміливий льотчик. Навішо ж було вигадувати, скажітъ, пані Віро?“ // „Неzkе́ je to jméno. I Gagarin byl odvážný pilot. Řekněte, pani Věro, pročpak jste si vymýšlela??. Tamtéž, s. 289-290.

29 Prezentace knihy na Lvovském fóru vydavatelů v roce 2017. [Online: 19. 7. 2020 https://starylev.com.ua/ news/dekomunizaciya-rodynnyh-istoriy-u-novomu-romani-viktoriyi-amelinoyi-dim-dlya-doma].

30 FOER, Jonathan Safran: Naprosto osvětleno. Praha: BB art, 2005, s. 158.

31 „Взагалі-то ие навіть зручно, що я собака. Будь я людиною, до ивого дня дуже би втомився від однієї лише необхідності вирішити, якою саме мовою розповісти чю історію - українською чи російсъкою...“. // „Jе сеlkет dobře, že jsem pes. Kdybych byl člověkem, byl bych už strašně unavený od jediného rozhodnutí, jakým jazykem příběh vyprávět - ukrajinsky nebo rusky..." AMELINA, Viktorija: Dim dlja Doma. Lviv: VSL, 2017, s. 11. 
щло не розуміє. В иій його наӥвній відвертості, де те, що зруйноване, так $і$ виглядає зруйнованим, і зникла синагога виглядає лише зниклою синагогою, - місту ніхто не повірить. Ніхто не побачить його."32

V románě Di̊m pro Doma potkáváme postavy s různými kořeny a kulturou, což pro město Lvov vzhledem k historickým událostem není divné a celý dům na ulici Halana je jakýmsi odrazem celé Ukrajiny - lidí z různých koutů Sovětského svazu, kteří mluví různými jazyky, mají různé tradice, ale nějak tak zbyli jeden pro druhého, smíruili se se svým neustálým trápením a nyní mohou doufat v budoucnost svých dětí, které už budou znát odpovědi na nezodpovězené otázky. Marusja a Mašino dítě na konci příběhu představují totiž novou generaci, tentokrát už určitě Ukrajinců, i když stále poznamenanou minulostí. A tak možná v dnešní době není důležitý původ a rodokmen, ale domov přítomný, jelikož dům je tam, kde se na nás pamatuje: „Дім там, де тебе пам’ятаютъ, - розпорошений, як уламки замерзлих річок над Землею. Я можу зараз сказати «моє місто», та це так само безглуздо, як сказати «моє повітря». [...] Дім наш, доки він в нас.“33

Žánrově Di̊m pro Doma není literaturou faktu, je to celková fikce, nicméně napsaná realistickým způsobem - je to kuriózní deník domácího mazlíčka, na druhou stranu však není chronologicky seřazen, protože se pro psa čas nevyměřuje hodinami a dny. V jistém slova smyslu jsou to i paměti zvířete, plné dětské naivity, veselé, a tak trochu ironické. Možná to zní ještě bizarněji, obzvlášt́, když se v první kapitole románu dozvíme, že vypravěč již nežije. Není to ani historický román, ale dějinám se nevyhýbá. Patrně chundelatý pes Dom je jediný, kdo svede nestranně převyprávět tento příběh o nelehkém období východní Evropy, o osudu jejích obyvatel a měst.

Podobnost koexistenčního ovlivňování obyvatel a města najdeme i v dalším současném ukrajinském románě od Jvana Kozlenka Tanger (2017). Tentokrát se však přesuneme ze západu Ukrajiny trochu jižněji, do neméně historicky bohaté Oděsy.

V románě Dưm pro Doma se autorka snaží tak trochu vyvrátit mýtus o tom, že Lvov nikdy nebyl komunistický, znázorňuje, že přistěhovalci z různých koutů Sovětského svazu chtě nechtě měnili město tak, jak měnilo i ono je. Jinak tomu je v Kozlenkovově románě Tanger. Autor vytváří obraz Oděsy, kde mladí lidé hledají kulturní identitu svého města, která by nebyla ani sovětská, ani ruská, ani ukrajinská - je to neoddělitelná symbióza: „[...]українсъка культура не органічна, [...] вона здобуток, а не сировина."34

I zde jsou protagonisté nucení vracet se do minulosti, je to nezbytný bod odrazu. Je to pochopitelné, s ohledem na historickou pestrost Oděsy, kde se střetávali představitelé různých národů a kultur: „Молдавани, турки, греки, євреї і росіяни пили разом i розмовляли кожен зі свойм акиентом на якомусь малозрозумілому, але досить мелодійному

32 „Lvov zatím nerozumi. V takové té své naivní upřimnosti, kde to, co je zničeno, stále vypadá zničeně, a zbouraná synagoga vypadá jenom jako zbouraná synagoga, nikdo městu neuvěř́. Nikdo ho neuvidí. "AMELINA, Viktorija: Dim dlja Doma. Lviv: VSL, 2017, s. 138.

33 „Dưm je tam, kde se na vás pamatuje. Rozptýlen jako trosky zamrzlých řek nad Zemi. Ted’ mohu ř́ci „moje město“, ale je to stejně absurdní jako ř́kat „můj vzduch“. [...] Dům je náš, dokud je v nás.“ Tamtéž, s. 381.

$34[\ldots]$ ukrajinská kultura neni organická [...] je nabytí a neni surovina." KOZLENKO, Jvan: Tanžer. Kyjiv: VD Komora, 2017, s. 150. 
apro. “35 A tak na stránkách románu ožívají historické události začátku 20. století, těsně spojené s válečnou kariérou Nikifora Alexandroviče Grigorjeva, polovojenského vůdce známého pro své četné přechody mezi válčícími stranami a antisemitismus. ${ }^{36}$ Potkáme zde i další historické postavy tohoto období, např. generálmajora Alexeje Grišina-Almazova, vojevůdce Grigorije Ivanoviče Kotovského, vojenského velitele Nikolaje Shillinga, Viktora Sokyru-Jachontova a další, kteří zanechali svou stopu v tomto městě. Hlavní hrdina prožívá Oděsu ve všech rovinách, podobně jako pes Dom z románu Viktorie Ameliny, vidí nesmazatelné pozůstatky minulých událostí na ulicích města: „[...] на безлюднім бульварі, де мало шо змінилося за останне століття, він виразно побачив тріумфальну ходу григор'євської армї, яка здолавши опір франиузів та греків, на початку квітня 1919 року переможно ввійшла в місто“"37. Začátky obou staletí, jak dvacátého, tak i jednadvacátého, se těsně proplétávají a postavy, představující v románě dnešní generaci, se potakávají s nejednoznačností historických faktů, která vzbuzuje stále více otázek: „[...] як буmu з тим же Григор'євим? Герой чи паскуда? Рятівник ии зрадник? Надто багато питанъ. "38

Kulturní stránka je pro samotného autora a představitele mladé generace Oresta ztvárněného v próze neméně důležitá, protože Oděsa je město, které: „[...] на зламi століть болісно переживало кризу культурної ідентичності..." ${ }^{39}$. Možná z tohoto důvodu je podstatný návrat do kulturního života Ukrajiny 20. let minulého století. Najdeme zde nejenom nejvýznamnější osobnosti ukrajinské literatury této doby - Jurije Janovského, Mychajl’a Semenka, Mykolu Bažana, Oleksandra Dovženka, ale i ruské literatury - Aleksandra Kuprina, Ivana Bunina ${ }^{40}$, Teffi (Nadežda Lochvickaja), jejichž pobyt a působení měnily Oděsu na centrum uměleckého střetávaní, kde nemohli chybět ani méně slavní oděští autoři - básnici futuristé, členové seskupení Zelená lampa (1917-1919) v čele s Anatolijem Fioletovem, představitelé „oděské“ literární školy (1920): Isaak Babel, Valentin Katajev, Jurij Oleša, Ilja Ilf, Jevhen Petrov, Eduard Bagritskij, Semen Kirsanov, Vira Inber, Lev Slavin ${ }^{41}$. Pochopitelně, že kolem filmového studia se točili nikoli jen spisovatelé, ale i herci (v románu - baletní tanečnice Ida Penzo), malírí (Vasyl Kryčevskyj), kameramani (Danylo Demuckyj) aj. Vše to nastiňuje bohatost kulturního života Oděsy, přibližuje ji k uměleckému bohémství Evropy, proměňuje město na dobrý př́iklad tehdej-

35 „Moldavané, Turci, Řekové, Židé a Rusové spolu pili a každý mluvil s osobitým př́zvukem, používali jakýsi málo srozumitelný, ale docela libozvučný argot." Tamtéž, s. 53.

36 FAJTELBERK-BLANK, Viktar: Aděsa v epochu vojn i revoljucij: 1914-1920. Aděsa: Oprimum, 2008, s.211.

37 „na opuštěném bulváru, kde se za posledni stoleti nic nezměnilo, jasně viděl triumfálni pochod armády Grijorjeva, která začátkem dubna 1919 vitězně vstoupila do města po překonáni odporu Francouzů a Řeků." KOZLENKO, Jvan: Tanžer. Kyjiv: VD Komora, 2017, s. 23.

38 „[...] jak být třeba s Grigorjevem? Je to hrdina nebo parchant? Spasitel nebo zrádce? To je príliš mnoho otázek." Tamtéž, s. 2.

39 „[...] na přelomu staleti bolestivě prožívá krizi kulturni identity.... "Tamtéž, s. 187.

40 Vzpomínky na pobyt v Oděse nejdeme v jeho knize pamětí Окаянные дни (1918), v českém překladu Proklaté dny (2006).

41 Díla těchto autorů jsou spojená mnoha běžnými rysy, jako je použití zvláštního oděského dialektu s výpůjčkami z jidiš a ukrajinštiny, zdůrazňují regionální kulturní rysy, používají satiru a stala se kánonem „oděské literatury“. KOZLENKO, Jvan: Tanžer. Kyjiv: VD Komora, 2017, s. 117. 
ší všestrannosti: „[...] багатонаиіональний та строкатий мегаполіс, такий собі атавізм у зануреній у морок наиіоналізмів міжвоєнній Європі. “42

Tanger je svérázným odhalením opravdové Oděsy, osvobozené od jejího sovětského vnímání jako turistické odpočinkové destinace. A zejména takový pohled na minulost pomáhá percipovat nejen přítomnost, ale i pro umění nelehkou komunistickou dobu. Autor dokonce uvádí, že minulost je to jediné, k čemu musejí vzhlížet mladí: "Для нової начї має існувати лише затяжне минуле та запаморочливе майбутнє, якого, втім, вона, найпевніше, ніколи не побачить. Адже нормальне теперішнє - розкіш помираючих кульmyp."43

Ve své prvotině se Jvan Kozlenko snaží vytvořit neviditelný můstek mezi epochami, ztotožňuje postavy minulosti s těmi dnešními. A viditelně poukazuje na zchátralost kultury v době Sovětského svazu, po které se těžko navrací k životaschopnosti: „Танжеp належить своєму місту й часові, епосі культурного вакууму, спричиненого втратою зв'язку Одеси з давнвою метрополією $і$ болісним переходовим етапом визнання своєї нової украйнсъкої ідентичності." 44

Klíčovou časovou rovinou v románě však zůstává milénium, proto zde najdeme př́itomnost pro ukrajinskou prózu příznačného tématu hledání své identity v době neurčenosti a nejistoty, postavy těchto próz jsou často zahozené do depresivního, ohroženého, neuspořádaného a k životu nepřizpůsobeného prostoru, ve kterém na ně obvykle číhají nebezpečí a pasti, a kde cesty přivádí do neznáma. ${ }^{45}$

Postavy mladých lidí ve věku 20 až 30 let, které pro svo̊j román vybírá spisovatel, se cítí být novou generací a na přelomu staletí se potýkají s již mnohokrát zmíněným znejistěním své existence a budoucnosti: „[...] наше покоління було занурене в езотерику. Безпросвітність, розгубленість і страх перед майбутнім, криза світогляду, параліч волі та ініиіативи як наслідок післярадянсъкого виховання... “46

Marko Andrejčyk ve své práci Intelektuál jako hrdina ukrajinské prózy 90. let 20. století poznamenává, že ukrajinští spisovatelé se po oslavě nezávislosti potkávají s velkým zklamáním a nesplněnými očekáváními. V jejich dílech se objevují postavy s „nemocnou duší“, s jakousi psychickou odchylkou, a proto nezapadají do nové reality, která neodpovídá jejich dřívějším touhám a představám o svobodném státě. Často tak podléhají alkoholu, bez kterého prostě nemohou zařídit své každodenní záležitosti. Jestli poezie

42 „[...] mnohonárodnostni a pestré velkoměsto, jakýsi atavismus v temnotě národnosti meziválečné Evropy. “ Tamtéž, s. 194.

43 „Pro novou národnost musi existovat jen zdlouhavá minulost a závratná budoucnost, kterou však pravděpodobně nikdy neuvidi. Vždyt’ normálni př́tomnost je koneckonců honosnost umírajicích kultur. "Tamtéž, s. 29.

44 „Tanger patři svému městu a času, době kulturniho vakua zpuisobené ztrátou spojeni Oděsy se starou metropoli a bolestivým přechodem k poznáni jeji nové ukrajinské identity. "Tamtéž, s. 197.

45 HUNDOROVA, Tamara: Pisljačornobylska bibloteka. Ukrajinskyj literaturnyj postmodernizm. Kyjiv: Krytyka, 2005, s. 137-176.

46, „[...] naše generace byla ponořena do esoteriky. Nevědomost, zmatek a strach z budoucnosti, krize náhledu na svět, ochromeni vuile a iniciativy $v$ di̊sledku postsovětské výchovy..." KOZLENKO, Jvan: Tanžer. Kyjiv: VD Komora, 2017, s. 189. 
a tajemné literární schůze a čtení byla předtím útěkem od socialistických všedních dnů, po roce 1992 se jím stává alkohol. ${ }^{47}$

Román Tanger je dalším znázorněním světa mladých, kteří prožívají přechodné období svého života a stojí na rozcestí před výběrem správné životní dráhy. Otázka směřování života je v literatuře etablovaná odjakživa, proto je (samo)zřejmé, že i současná literatura mladých pro mladé ji před námi otevírá: „[...] молодi, обдаровані люди... [...] у них не було майбутнъого. Вони втратили зв'язок із минулим." ${ }^{8}$

V románech Dưm pro Doma a Tanger je patrné formování představitele dnešní Ukrajiny, ovlivněného nejen historickými a politickými událostmi, ale i oboustranně vzájemným působením měst a jejich obyvatel. Právě minulost by měla pro dnešní generaci být odrazovým bodem v hledání sebe sama. Na ni bychom však měli nahlížet s opatrností, bez nerozvážného odsuzování, které je příznačné současné době.

V obou případech se jedná o příběhy dvou rozmanitých měst západní a jižní Ukrajiny, dvou odlišných, ale i v něčem si tak blízkých světů. Autoři těchto děl mapují pro čtenáře mozaiku ukrajinské identity, která se na přelomu staletí namáhavě formovala. A tudíž oba spisovatelé svými postavami odráží povědomí, nervozitu a neklid své generace v nejistém období konce 20. a začátku 21. století.

\section{Literatura}

AMELINA, Viktorija: Dim dlja Doma. Lviv: VSL, 2017.

ANDREJČYK, Marko: Intelektual jak heroj ukrajins'koji prozy 90-ch rokiv XX stolittja. Lviv, 2014.

BUNIN, Ivan: Okajannyje dni. Moskva: Eksmo, 2011.

FAJTELBERK-BLANK, Viktar: Aděsa v epochu vojn i revoljucij: 1914-1920. Aděsa: Oprimum, 2008. FIALOVÁ, Alena (ed.): V souřadnicích mnohosti. Česká literatura proni dekády jednadvacátého století $v$ souvislostech a interpretacich. Praha: Academia, 2014.

FOER, Jonathan Safran: Naprosto osvětleno. Praha: BB art, 2005.

FOǨT, Bohumil: Úvod do sémantiky fikčních světu. Brno: HOST, 2005.

HUNDOROVA, Tamara: Pisljačornobylska bibloteka. Ukrajinskyj literaturnyj postmodernizm. Kyjiv: Krytyka, 2005.

KAUTMAN, František: $O$ českou národni identitu. Praha: Pulchra, 2015.

KOZLENKO, Jvan: Tanžer. Kyjiv: VD Komora, 2017.

KRATOCHVIL, Alexandr: Pamět a trauma pohledem humanitnich věd: Komentovaná antologie teoretických textů. Praha: Akropolis, 2015.

NAJENKO, Mychajlo: Istorija ukrajinskoho literaturoznavstva i krytyky: Navčalnyj posibnyk. Kyjiv: Akademija, 2010.

47 ANDREJČYK, Marko: Intelektual jak heroj ukrajinskoji prozy 90-ch rokiv XX stolittja. Lviv, 2014.

48, „...] mladí, nadaní lidé... [...] Neměli žádnou budoucnost. Ztratili spojitost s minulosti.“ KOZLENKO, Jvan: Tanžer. Kyjiv: VD Komora, 2017, s. 194-195. 


\section{Internetové zdroje}

Centr Razumkova: Osnovni zasady ta šljachy formuvannja spilnoji identyčnosti hromadjan. Informacijno-analityčni materiály do kruhloho stolu 12 kvitnja 2017 roku. Kyjiv: Centr Razumkova, 2017. (https://razumkov.org.ua/images/Material_Conference/ 2017_04_12_ident/2017-Identi-3.pdf).

Prezentace knihy na Lvovském fóru vydavatelů v roce 2017. [online 19. 7. 2020: https:/ /starylev.com. ua/news/dekomunizaciya-rodynnyh-istoriy-u-novomu-romani-viktoriyi-amelinoyi-dim-dlya-doma].

ULJURA, Hanna: Dvi knyžky pro radjanske mynule. Viktorija Amelina „Dim dlja Doma“ [online 20. 4. 2019: https://lb.ua/culture/2017/09/06/375749_tilki_plach_nova_ukrainska_proza.html].

\section{Mgr. Krystyna Kuznietsova}

Ústav slavistiky

Filozofická fakulta, Masarykova univerzita

Arna Nováka 1, 60200 Brno, CZ

282051@mail.muni.cz 
